\title{
Do Implants Closed with Healing Cap Show Less Marginal Bone Loss After First Year?
}

\author{
Esra Beyler(0000-0003-0824-1629) ${ }^{\alpha}$, Nur Altıparmak(0000-0003-0870-4523 ${ }^{\alpha}$, Sıdıka Sinem Akdeniz(0000-0001-7597-9469) ${ }^{\alpha}$
}

Selcuk Dent J, 2021; 8: 652-657 (Doi: 10.15311/selcukdentj.749344)

\begin{abstract}
Do Implants Closed with Healing Cap Show Less Marginal Bone Loss After First Year?

Background: Early peri-implant crestal bone loss during the healing period and the first year on function, is often greater than the bone loss occurring in the following years. Several factors affecting marginal bone loss have been described; such as surgical trauma, flapped or flapless procedures, occlusal overload, microgap and implant crest module. The aim of this study; was to compare the amount of first year peri-implant bone loss in implants closed with cover screw or healing cap.
\end{abstract}

Methods: Patients with same brand, posterior single tooth implants included in this prospective study and divided into two groups. In group I, after implant placement healing cap was placed while in group II, cover screw was placed before primary closure. Panoramic radiographs, taken before and after the implant surgery and after 1 year follow up, were used in bone loss evaluations. Peri-implant bone loss measurements were performed digitally in computer assisted software programme.

Results: Thirty implants included in the study with fourteen implants in group I and sixteen implants in group II. There were no perioperative or postoperative complications and no implant failure in all patients. After the first year, mean marginal bone loss was $0.7014 \mathrm{~mm}(0.2477 \mathrm{~mm}$ standard deviation) in group I and $1.3156 \mathrm{~mm}(0.0943 \mathrm{~mm}$ standard deviation) in group II. This $0.6142 \mathrm{~mm}$ difference was found statistically significant.

Conclusion: Placing healing cap instead of cover screws may prevent periosteal tissue pressure on the crestal bone and reduce the amount of marginal peri-implant bone in the first year.

\section{KEYWORDS}

Alveolar bone loss; Dental implant, Single-tooth; Tooth loss

Early marginal bone loss defined as a remodeling process occurring in the first year after implant placement. Early peri-implant bone loss which is seen on the first year, is generally greater than the bone loss occurs in the following years. 1 In an osseointegrated implant, the breakdown of the implant and oral tissues interface starts from the crestal region.1,2 Early marginal bone loss during the healing period and the first year on function $(0.9-1.6 \mathrm{~mm})$ is higher than following years $(0.05$
Öz

Yerleştirme Sonrası İyileşme Başığı ile Kapatılan İmplantlarda İlk Yılda Marjinal Kemik Kaybı Daha Az mı Görülür?

Amaç: Implant tipinden bağımsız olarak iyileşme periyodu ve fonksiyondaki ilk yılda görülen erken dönem implant çevresi krestal kemik kaybı genellikle ilerleyen yıllarda oluşan kemik kaybından daha fazladır. Günümüze kadar, marjinal kemik kaybını etkileyen birçok faktör tanımlanmıştır. Bunlar; cerrahi travma, flapsiz ya da flap kaldırılan prosedürler, mikrogap, krestal implant modülü olarak sıralanmaktadır. Bu çalışmanın amacı; yerleştirme sonrası kapama vidası ile primer kapatılan implantlar ile iyileşme başlığı ile kapatılan implantların ilk yılda görülen implant çevresi kemik kaybına etkisini karşılaştırmaktır.

Gereç ve Yöntemler: Bu prospektif çalışmaya 30 hasta dahil edilmiştir. Kemik seviyesi, "platform switch" özellikli, aynı marka, konik, posterior tek diş implantlar yerleştirilmiş hastalar iki gruba ayrılmıştır. Birinci grup, implant yerleștirimesini takiben iyileşme başlığı takılan implantlardan oluşurken ikinci grupta implantlar kapama vidası ile primer olarak kapatımıştır. Cerrahi öncesi, hemen sonrası ve 1 yıllık takip sonrası alınan panoramik radyograflar kemik kaybı değerlendirilmesinde kullanılmışıı. İmplant çevresi kemik kaybı miktarları, dijital olarak bilgisayar yazılımı aracılığıyla ölçülmüştür.

Bulgular: Çalışmaya, iyileşme başlığı grubunda 14 adet ve kapama vidası grubunda 16 adet, toplamda 30 implant dahil edilmiștir. Perioperatif ve postoperatif dönemde herhangi bir komplikasyon görülmemiştir. Çalışma sonunda hiçbir implant başarısızlığı görülmemiştir. Birinci yıl sonrası iyileşme başlığı grubunda ortalama $0,7014 \mathrm{~mm}$ (0.2477 $\mathrm{mm}$ standart sapma) marjinal kemik kaybı görülürken, kapama vidası yerleştirilen ikinci grup implantlarda ortalama $1,3156 \mathrm{~mm}$ (0.0943 mm standart sapma) kemik kaybı ölçülmüştür. İki grup arasındaki 0,6142 mm'lik fark istatistiksel olarak anlamlı bulunmuştur.

Sonuç: Yerleştirme sonrası kapama vidası yerine iyileşme başlığı yerleştirmek, krestal kemik üzerinde periost basıncını önleyerek özellikle ilk yılda görülen marjinal kemik kaybını önleyebilir.

\section{ANAHTAR KELIMELER}

Alveoler kemik kaybı; Diş implantı, Tek diş; Diş kaybı

$\mathrm{mm}-0.13 \mathrm{~mm}) \cdot^{3-6} \mathrm{~A}$ mean peri-implant crestal bone loss between $0.9 \mathrm{~mm}$ to $1.6 \mathrm{~mm}$ during the first year of functioning has been accepted as unextraordinary in successfully osseointegrated implants. ${ }^{7-9}$ Annually a mean marginal bone loss less than $0.2 \mathrm{~mm}$ is expected in a successful dental implant, in the following years. ${ }^{7-9}$

Survival of dental implants is based on the relationship between implant and oral tissues. Marginal bone level stability around implants has been used as one of the main criteria for implant success. ${ }^{10}$ Peri-implant bone loss around

${ }^{\alpha}$ Başkent University Faculty of Dentistry, Department of Oral and Maxillofacial Surgery, Ankara, Turkey. 
may result in the failure of osseointegration. Implant failures are often associated with implant mobility due to marginal bone loss. Significant peri-implant marginal bone loss occurs in the first year but this stabilizes thereafter. ${ }^{11}$ Therefore it is important to minimize the marginal bone loss at early stages. Possible etiologies of early peri-implant marginal bone loss have been reported and possible approaches have been discussed to minimize the amount. ${ }^{1}$ According to the literature, initial peri-implant marginal bone loss, during the first year, may be influenced by a number of factors such as surgical trauma, occlusal overload, microgap, biologic width, implant crest module, and flapped or flapless surgical procedures. ${ }^{1}$ However there is no consensus on why greater marginal bone loss is seen on the healing period and the first year of loading. Lately, periosteal pressure of primary mucosal closure with tight suturing has been discussed as a possible etiologic factor on early stage bone loss after implant placement. This study based on the theory that using $2 \mathrm{~mm}$ healing cap instead of cover screw may eliminate flap pressure around implant. The aim of this study; was to compare the amount of first year peri implant bone loss between implants with cover screw and implants closed with healing cap.

\section{MATERIALS AND METHODS}

This study was approved by Baskent University Institutional Review Board with Project Number DKA19/27 and supported by Baskent University Research Fund. This study was conducted with Declaration of Helsinki 2008.

All patients signed informed consent form before implant surgery. Patients with same brand, platform switch, posterior single tooth, bone level tapered implants $(4.3 / 10 \mathrm{~mm}$, Nobel Biocare AG Kloten, Switzerland) included in the study and divided into two groups. After $0.12 \%$ chlorhexidine mouth rinse, local anesthesia was obtained at the surgery site. Incision on the alveolar ridge was made keeping a minimum $1.5 \mathrm{~mm}$ buccal and lingual keratinized soft tissue. After elevation of mucoperiosteal flap, implant site was prepared according to the manufacturer's recommendations under saline irrigation. Implants were inserted with $35 \mathrm{Ncm}$ torque. After obtaining primary stability of implants subjects were randomly assigned to one of the groups according to a computer-generated random list. All surgeries were performed by the same surgeon, the surgeon was blinded until the implant stabilization procedures had been completed. In group I, after implant placement 2 $\mathrm{mm}$ healing cap was placed. While in group II, cover screw was placed before primary closure with sutures.

Patients were given same postoperative regimen. Pain control medications, amoxicillin $1000 \mathrm{mg} \mathrm{(2 \times 1/5}$ days), and $0.12 \%$ Chlorhexidine mouth rinse $(3 \times 1 / 7$ days) were prescribed. In the second group, after waiting for the osseointegration period, healing cap was placed with a small gingival incision just above the cover screw. All implants were loaded with screwretained ceramic crowns, two to four months after surgery according to jaw side.

Patients with uncontrolled systemic diseases, chronic periodontitis and smoking habits, implant sites required bone augmentation, implants placed in fresh extraction sockets and cases needed for 2nd flap opening during healing cap placement were excluded from the study. Keratinized tissue width in milimeters was measured with a periodontal probe at the buccal aspect of the implant from the free gingival margin to the mucogingival junction. Patients with keratinized mucosa less than $2 \mathrm{~mm}$ also excluded from the study.

Digital panoramic radiographs which were taken before (T1) and after the implant surgery (T2) and after first year on function (T3) were used in bone loss evaluations. Digital panoramic radiographs and measurement of one of the patients are shown in Figure 1 and Figure 2.

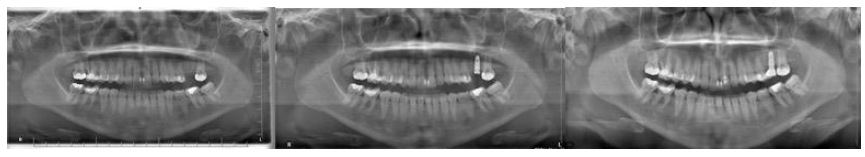

Figure 1

Panoramic radiographs taken before (T1), immediate after (T2) and one year after (T3) implant placement.

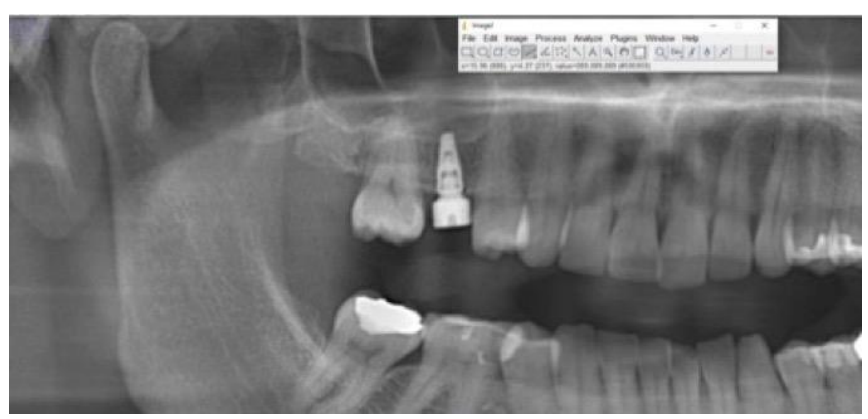

Figure 2

Example of bone level measurements on ImageJ programme.

All panoramic radiographs were taken via Veraviewepocs 2D (J. Morita Corp., Japan) X-ray device. Peri-implant bone loss measurements were performed digitally in computer assisted software programme (ImageJ, USA). Marginal bone loss was measured from implant shoulder to the margin of bone contact mesially and distally. In order to insure reliability of the radiographic measurements, twenty percent of the patients were randomly selected and 
remeasured after two weeks to ensure intra-observer reliability, and the Intraclass Correlation Coefficient (ICC) was calculated.

The data obtained were statistically analyzed using the Kolmogorov-Smirnov, Shapiro-Wilk tests and Indepedent samples t-test in IBM SPSS Statistical Package for the Social Sciences (SPSS) Version 25 software package (IBM SPSS Inc., United States). A significance level of 0.05 was predetermined.

\section{RESULTS}

Thirty patients with a total of 30 implant included in the study. Healing cap group (Group 1) consisted of fourteen implants in healing cap group and cover screw group (Group 2) consisted of sixteen implants. There were no perioperative or postoperative complications and no implant failure in all patients. Patient demographic characteristics were summarized as; 18 male (60\%) and 12 female (40 $\%$ ), with an average age of 41.75 (ranging between 24 and 60 years). The regions and the number of the implants placed are shown in the Table 1.

Table 1.

The regions, number of the implants placed in the mouth

\begin{tabular}{cccccc} 
Implant & Jaw & Diameter/Length & Premolar & Molar & Total \\
\cline { 1 - 4 } Group I & Maxilla & $4.3 / 10 \mathrm{~mm}$ & 3 & 4 & \multirow{2}{*}{14} \\
\cline { 2 - 5 } & Mandible & $4.3 / 10 \mathrm{~mm}$ & 2 & 5 & \\
\hline \multirow{2}{*}{ Group II } & Maxilla & $4.3 / 10 \mathrm{~mm}$ & 2 & 6 & \multirow{2}{*}{16} \\
\cline { 2 - 5 } & Mandible & $4.3 / 10 \mathrm{~mm}$ & 2 & 6 & \\
\hline Total & & & & & 30 \\
\hline
\end{tabular}

After the first year on function, mean $0.7014 \mathrm{~mm}$ (0.2477 $\mathrm{mm}$ standard deviation) marginal bone loss was observed in group I whereas; in group II mean $1.3156 \mathrm{~mm}(0.0943 \mathrm{~mm}$ standard deviation) was measured. Mean bone loss in both groups are shown in the Table 2. This $0.6142 \mathrm{~mm}$ difference between two group was found statistically significant $(p<0.001)$

Table 2

\section{Mean marginal bone loss according to implant} groups.

\begin{tabular}{|lccc|}
\hline Implant & $\mathbf{n}$ & Mean bone loss & Std. deviation \\
\hline Healing cap (Group I) & 14 & $0,7014 \mathrm{~mm}$ & 0,24772 \\
\hline Cover screw (Group II) & 16 & $1,3156 \mathrm{~mm}$ & 0,09437 \\
\hline
\end{tabular}

\section{DISCUSSION}

This study's main clinical parameter is peri-implant crestal bone loss since it is one of the most crucial clinical criteria for implant success. ${ }^{12}$ Marginal bone loss is utmost importance in both the early and long term as a reduction in bone levels can lead to loss of the dental implant. ${ }^{12}$

Different radiologic methods including two dimensional and three dimensional images have been suggested to follow bone levels around dental implants. ${ }^{13}$ Major disadvantage of two dimensional evaluations is measurements are limited to only interproximal areas. ${ }^{14,15}$ Cassetta et al. ${ }^{16}$ studied the difference between periimplant marginal bone level measurements evaluated intraoperatively and measurements obtained via periapical radiography. They concluded that the periapical radiography measurements significantly overestimated the level of marginal bone loss when compared to surgical measurements. ${ }^{16}$ Multiple studies have compared periapical radiography with panoramic radiography for peri-implant bone level assessments. Zechner et al. ${ }^{17}$ suggested that both panoramic and periapical radiography bone loss measurements were comparable in terms of the precision. Similarly, Gutmacher et al. ${ }^{18}$ found high positive correlation between panoramic and periapical radiograph bone level measurements. Vazquez et al. ${ }^{19}$ reported that proximal bone-implant measurements obtained with panoramic radiography were as reliable and repeatable as periapical radiography. The choice of imaging in our study thus supported by the literature. ${ }^{18}$ The high exposure dose and the expense of CBCT makes it ethically controversial for routine implant controls in marginal bone loss. Hence, in this study panoramic radiographs used for this mean for a standart protocol for postoperative implant controls in relationship with both bone and other anatomic structures such as mandibular canal or maxillary sinus floor. The ICC values, which were calculated for intra-observer reliability, exhibited high repeatability in the periimplant bone loss measurements. One of the limitations of the study is the disadvantage of two dimensional panoramic imaging is the lack of measurements in the vestibular and lingual aspects.

Recently, studies have been published in placing implants with the one staged implant surgery protocol. ${ }^{20-24}$ Still the question of whether healing period in two staged or one staged protocol is better for the prognosis of implants remains unclear. ${ }^{25}$ Initial marginal bone loss which is seen in the first year may be affected by a number of parameters such as surgical trauma, elevation of mucoperiosteal flap, microgap, soft tissue width, immune response and occlusal overload. Nevertheless, the actual reason for the crestal bone 
Nevertheless, the actual reason for the crestal bone loss is still highly controversial. ${ }^{26}$ Elevation of periosteum has been theorized as a possible factor in crestal bone loss. 1 It was reported that after periosteal elevation, approximately $0.8 \mathrm{~mm}$ horizontal bone loss is expected..$^{27}$ Nevertheless, the bone loss seen around especially at two-staged implants is vertical and has been around $0.2 \mathrm{~mm}$ to $1.3 \mathrm{~mm} .^{3,28}$ Besides, the bone loss which is seen around dental implant is characterized by "saucerization", rather than a horizontal loss. ${ }^{29}$ Thus, the periosteal elevation theory has these inadequacies. On the other hand, studies have revealed that numerous disconnection and reconnection of implant components jeopardized the tissue barrier surrounding implant and resulted in marginal bone loss. A recent study comparing effects of one-staged vs two-staged placement of prosthetic components showed that remarkable bone maintenance during healing period on one-staged surgery. ${ }^{30}$ Maintenance of marginal bone levels around implants is a major challenge in implant dentistry. Several precautions have been suggested such as one step implant protocol, submerged placement of implants, immediate placement of prosthetic abutments, using inital provisional crowns and flapless surgery. ${ }^{31}$

This study was designed on the theory that tight primary suturing may have a aggravating factor on early peri-implant bone loss and using $2 \mathrm{~mm}$ healing cap at the time on implant placement may have a preventive role.

Early marginal bone loss is a non-infective remodeling process of the bone occuring within the first year after implant placement. This process has a multifactorial etiology, being influenced by both surgical and prosthetic factors including hard and soft tissue structures. ${ }^{10}$ This study included dental implants with > $2 \mathrm{~mm}$ of keratinized tissue at the time of implant placement and studied changes only in bone tissue. Multiple clinical factors should be taken into consideration for future studies is needed.

\section{CONCLUSION}

Although many hypotheses exist, the mechanism of peri-implant marginal bone change and the actions for prevention have not been clearly explained yet. In our theory, placing healing cap instead of cover screws on implants may prevent the periosteal tissue pressure on the crestal bone and reduce the amount of marginal peri-implant bone loss which is commonly seen in the first year period. More studies with larger sample sizes and split-mouth designed required to conclude a clear theory about preservation of peri-implant bone levels.

This study was approved by Baskent University Institutional Review Board with Project Number DKA19/27 and supported by Baskent University Research Fund. 


\section{REFERENCES}

1. Oh TJ, Yoon J, Misch CE, Wang HL. The causes of early implant bone loss: myth or science? Journal of periodontology. 2002;73(3):322-33.

2. Alshehri ADMA. The maintenance of crestal bone around dental implants. Implants. 2011;2:20-4.

3. Adell R, Lekholm U, Rockler B, Brånemark P-I. A 15-year study of osseointegrated implants in the treatment of the edentulous jaw. International journal of oral surgery. 1981;10(6):387-416.

4. Adell R, Lekholm U, Rockler B, Brånemark $P$, Lindhe $\mathrm{J}$, Eriksson $\mathrm{B}$, et al. Marginal tissue reactions at osseointegrated titanium fixtures:(I). A 3-year longitudinal prospective study. International journal of oral and maxillofacial surgery. 1986;15(1):39-52.

5. Cox J, Zarb G. The longitudinal clinical efficacy of osseointegrated dental implants: a 3-year report. International Journal of Oral \& Maxillofacial Implants. 1987;2(2).

6. Jemt T, Lekholm U, Gröndahl K. 3-year followup study of early single implant restorations ad modum Brånemark. The International journal of periodontics \& restorative dentistry. 1990;10(5):340-9.

7. Albrektsson $T$, Zarb G, Worthington $P$, Eriksson A. The long-term efficacy of currently used dental implants: a review and proposed criteria of success. Int $\mathrm{j}$ oral maxillofac implants. 1986;1(1):11-25.

8. Smith DE, Zarb GA. Criteria for success of osseointegrated endosseous implants. The Journal of prosthetic dentistry. 1989;62(5):567-72.

9. Cassetta M. Immediate loading of implants inserted in edentulous arches using multiple mucosa-supported stereolithographic surgical templates: a 10-year prospective cohort study. International journal of oral and maxillofacial surgery. 2016;45(4):526-34.

10.Lombardi T, Berton F, Salgarello S, Barbalonga E, Rapani A, Piovesana F, et al. Factors influencing early marginal bone loss around dental implants positioned subcrestally: a multicenter prospective clinical study. Journal of clinical medicine. 2019;8(8):1168.

11.Taheri M, Akbari S, Shamshiri AR, Shayesteh YS. Marginal Bone Loss around Bone-Level and Tissue-Level Implants: A systematic Review and Meta-analysis. Annals of Anatomy-Anatomischer Anzeiger. 2020:151525.

12. Esposito M, Hirsch JM, Lekholm U, Thomsen P. Biological factors contributing to failures of osseointegrated oral implants,(I). Success criteria and epidemiology. European journal of oral sciences. 1998;106(1):527-51.
13. Serino G, Sato $H$, Holmes $P$, Turri A. Intra-surgical vs. radiographic bone level assessments in measuring peri-implant bone loss. Clinical oral implants research. 2017;28(11):1396-400.

14. Hollender L, Rockler B. Radiographic evaluation of osseointegrated implants of the jaws. Dentomaxillofacial Radiology. 1980;9(2):91-5.

15. Sewerin IP. Errors in radiographic assessment of marginal bone height around osseointegrated implants. European Journal of Oral Sciences. 1990;98(5):428-33.

16. Cassetta M, Di Giorgio R, Barbato E. Are intraoral radiographs reliable in determining peri-implant marginal bone level changes? The correlation between open surgical measurements and periapical radiographs. International journal of oral and maxillofacial surgery. 2018;47(10):1358-64.

17.Zechner W, Watzak G, Gahleitner A, Busenlechner D, Tepper G, Watzek G. Rotational panoramic versus intraoral rectangular radiographs for evaluation of peri-implant bone loss in the anterior atrophic mandible. International Journal of Oral \& Maxillofacial Implants. 2003;18(6).

18. Gutmacher Z, Machtei EE, Hirsh I, Zigdon-Giladi H, Horwitz J. A comparative study on the use of digital panoramic and periapical radiographs to assess proximal bone height around dental implants. Quintessence International. 2016;47(5).

19. Vazquez L, Nizamaldin Y, Combescure C, Nedir R, Bischof M, Dohan Ehrenfest D, et al. Accuracy of vertical height measurements on direct digital panoramic radiographs using posterior mandibular implants and metal balls as reference objects. Dentomaxillofacial Radiology. 2013;42(2):20110429.

20. Weber HP, Crohin CC, Fiorellini JP. A 5-year prospective clinical and radiographic study of nonsubmerged dental implants. Clinical Oral Implants Research. 2000;11(2):144-53.

21.Cochran DL, Jackson JM, Jones AA, Jones JD, Kaiser DA, Taylor TD, et al. A 5-year prospective multicenter clinical trial of non-submerged dental implants with a titanium plasma-sprayed surface in 200 patients. Journal of periodontology. 2011;82(7):990-9.

22. Ferrigno N, Laureti M, Fanali S, Grippaudo G. A long-term follow-up study of non-submerged ITI implants in the treatment of totally edentulous jaws: Part 1: Ten-year life table analysis of a prospective multicenter study with 1286 implants. Clinical Oral Implants Research. 2002;13(3):260-73.

23. Mericske-Stern R, Grütter L, Rösch R, Mericske E. Clinical evaluation and prosthetic complications of single tooth replacements by non-submerged implants. Clinical Oral Implants Research. 2001;12(4):309-18. 
24. Romeo E, Lops D, Margutti E, Ghisolfi M, Chiapasco M, Vogel G. Long-term survival and success of oral implants in the treatment of full and partial arches: a 7-year prospective study with the ITI dental implant system. International Journal of Oral \& Maxillofacial Implants. 2004;19(2).

25. Sánchez-Siles M, Muñoz-Cámara $D$, SalazarSánchez N, Camacho-Alonso F, Calvo-Guirado $\mathrm{JL}$. Crestal bone loss around submerged and non-submerged implants during the osseointegration phase with different healing abutment designs: a randomized prospective clinical study. Clinical oral implants research. 2018;29(7):808-12.

26. Naveau A, Shinmyouzu K, Moore C, Avivi-Arber L, Jokerst $\mathrm{J}$, Koka $\mathrm{S}$. Etiology and measurement of peri-implant crestal bone loss (CBL). Journal of clinical medicine. 2019;8(2):166.

27. Wilderman MN, Pennel BM, King K, Barron JM. Histogenesis of repair following osseous surgery. Journal of periodontology. 1970;41(10):551-65.

28. Misch CE, Dietsh-Misch F, Hoar J, Beck G, Hazen $\mathrm{R}$, Misch CM. A bone quality-based implant system: first year of prosthetic loading. Journal of Oral Implantology. 1999;25(3):185-97.

29. Hagiwara Y. Does platform switching really prevent crestal bone loss around implants? Japanese Dental Science Review. 2010;46(2):12231.

30. Molina A, Sanz-Sánchez I, Martín C, Blanco J, Sanz M. The effect of one-time abutment placement on interproximal bone levels and periimplant soft tissues: a prospective randomized clinical trial. Clinical oral implants research. 2017;28(4):443-52.

31.Praça L, Teixeira RC, Rego RO. Influence of Abutment Disconnection on Peri-implant Marginal Bone Loss: a randomized clinical trial. Clinical Oral Implants Research. 2020

Corresponding Author:

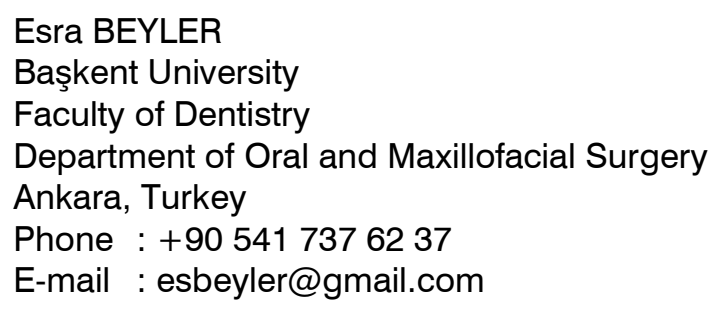

